\title{
An example of wind turbine structure
}

\author{
Marija Jelčić, M.Eng.C.E. \\ Mladen Kožul \\ University of Mostar, Faculty of Civil Engineering, Ph.D C.E. \\ mladen.kozul@gf.sum.ba
}

\begin{abstract}
The purpose of this paper is to develop structural design of a wind turbine foundation and tower. The structural modeling was performed in program Tower 7 . All structural elements are calculated according to the applicable regulations of Eurocode and National Annexes. The structure consists of a steel tower calculated in segments and a reinforced concrete foundation made in a monolithic design. The wind turbine tower is a steel tubular tower, while the foundation is made of reinforced concrete in a circular shape.
\end{abstract}

Keywords: structure, load, structural calculation, formwork plan

\section{Primjer konstrukcije vjetroagregata}

Sažetak: Cilj ovog rada je izrada projekta konstrukcije temelja i stupa vjetroagregata. Modeliranje konstrukcije izvršeno je u računalnom programu Tower 7 . Svi konstruktivni elementi su proračunati prema važećim propisima Eurocode-a i Nacionalnim dodacima. Konstrukcija se sastoji od čeličnog stupa proračunatog u segmentima te armiranobetonskog temelja izvedenog monolitnom izvedbom. Stup vjetroagregata je čelični cjevasti, dok je temelj armirano betonski, kružnog oblika.

Ključne riječi: konstrukcija, opterećenje, statički proračun, plan oplate 


\section{INTRODUCTION}

At the present time with growing awareness of the need to preserve the environment and reduce conventional energy production methods, there is a great interest of experts in the possibility of using alternative energy sources such as wind, solar, biodiesel and the like. Reserves of fossil fuels are disappearing faster and faster, climate change is becoming increasingly pronounced, and the use of energy obtained from renewable sources is becoming increasingly needed, and so wind energy, among others, is a great help and relief. In this paper, attention is focused on the construction method of a wind turbine foundation and tower.

The simplest definition describes a wind power plant as a group of closely positioned wind turbines, usually of the same type, exposed to wind of the same characteristics and connected to the electric power system. Wind turbines are rotating machines that convert the kinetic energy of wind into mechanical and then through electrical generators into electrical energy.

The use of wind energy dates back to a distant history when people traveled long distances by sailing ships, the success of which depended precisely on the renewable energy source - wind. From those ancient times until today, some of the maritime transport means still navigate in exactly the same way, using the same energy source.

The earliest known case of wind energy use dates from the $1^{\text {st }}$ century, when Heron's wind wheel was used to power an organ (Figure 1).

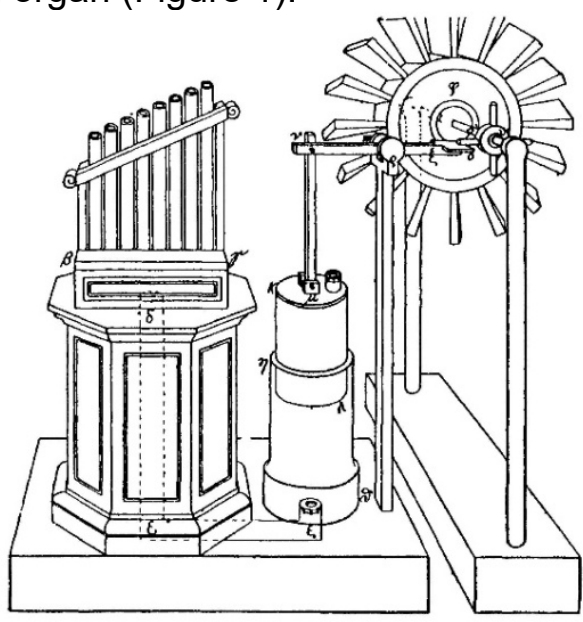

Figure 1. Heron's wind wheel

The first windmills for practical use are believed to have appeared as early as in the $7^{\text {th }}$ century in the area between Afghanistan and Iran (Figure 2), and were characterized by a vertical position of the rotation axis and rectangular sails. They were used to grind grain and pump water. Today, the development of wind power plants and the wind industry are growing at an enormous pace. The dimensions have increased approximately twice, and the generator powers have certainly increased tenfold (Figure 3).

In Europe, a capacity of approximately $134.6 \mathrm{GW}$ of wind energy is presently available, of which $94 \%$ is accounted for onshore wind turbines and the remaining $6 \%$ for offshore wind turbines. European Union countries are aiming to achieve the target of $20 \%$ energy from renewable sources already by this year. In order to achieve this target, each country has been adopting national laws and regulations relating to this subject.

Energy issues, especially those on renewable energy sources, have become very 
Jelčić, M., Kožul, M.

An example of wind turbine structure

important not only because of the poor environmental condition, but also because of the ever-increasing energy needs. Thus, for example, in the Netherlands, wind energy has been used for centuries now to drain wetlands, cut timber and exploit oil (Figure 4).

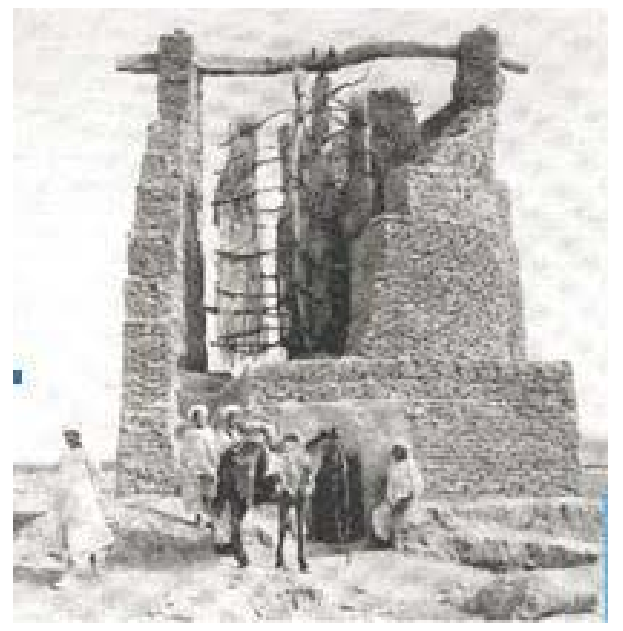

Figure 2. Windmill, $7^{\text {th }}$ century

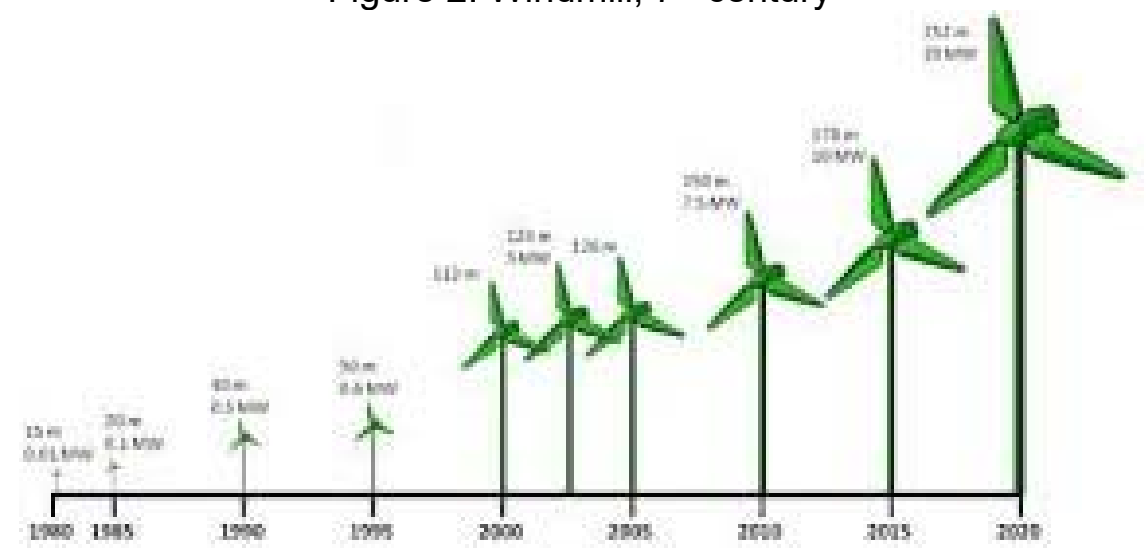

Figure 3. Progress in building wind power plants through the decades

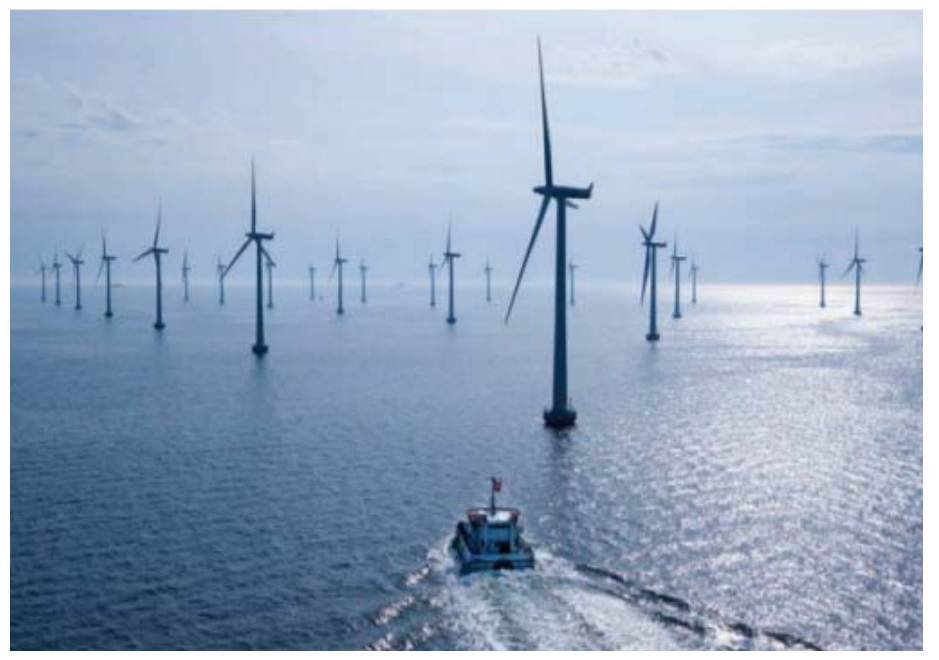

Figure 4. View of an offshore wind farm in the Netherlands 


\section{SOME TECHNICAL AND COMPUTATIONAL CHARACTERISTICS OF THE WIND TURBINE}

The altitude of the wind turbine is about 1500.0 meters. It consists of a steel tower, operating part - blades and a nacelle, and a foundation. The wind turbine tower is a steel tube 78 meters in height. The width of the tower varies, from 4240 millimeters at the connection with the foundation, to 2302 millimeters at the contact with the power-generating part of the wind turbine. The tower wall thicknesses range from 24 millimeters $(27 \mathrm{~mm})$ at the bottom of the tower to 15 millimeters $(18.20 \mathrm{~mm})$ at the top.

The tower consists of segments welded together to form three elements, which are interconnected by flanges and bolts. The joints are made of high-strength bolts (VV) of strength class 10.9 distributed as follows: 120 M39 on the base along the upper and lower foundation ring and $142 \mathrm{M} 42$ and $98 \mathrm{M} 42$ on the flanges. The bolts on the flanges are pretensioned with a force $F_{p}=710 \mathrm{kN}$. The quality of steel of the tower jacket is $\mathrm{S} 355 \mathrm{~K} 2+\mathrm{N}$ and $\mathrm{S} 355 \mathrm{~J} 2+\mathrm{N}$.

The wind turbine tower structure is calculated for two groups of loads. The extreme loads occurring during operation of the turbine ("Extreme loads") are taken into account first. The horizontal forces at the joint between the tower and the foundation are $-755.8 \mathrm{kN}$ (greater) and $-21.4 \mathrm{kN}$ (smaller), respectively, while the maximum vertical force is $2486 \mathrm{kN}$. The maximum torsional moment is $926 \mathrm{kNm}$, while the bending moments transferred from the tower to the foundation are $56404.9 \mathrm{kNm}$ and $2157.9 \mathrm{kNm}$, respectively.

The second group of loads, the action of which is analyzed, is the group of loads from the action of wind. The relevant wind load was obtained on the basis of the wind turbine location according to the wind speed map (10 minutes at a height of $10 \mathrm{~m}$ for a 50 -year return period) with HRN EN 1991-1-4:2012+NAD., on the very border of the Republic of Bosnia and Herzegovina with the Republic of Croatia. For this zone, the basic reference velocity $v_{b, 0}$ is $30 \mathrm{~m} / \mathrm{s}$, which gives a pressure $q_{b, 0}$ of $0.56 \mathrm{kN} / \mathrm{m}^{2}$, and with the coefficient of exposure $\left(c_{e}\right)$ of 4 for terrain category I gives the velocity of $60 \mathrm{~m} / \mathrm{s}$.

The calculation gave the natural period of the structure $T=3.28 \mathrm{sec}$, which resulted in a dynamic coefficient, with which the base load was increased by $50 \%$ (rotor and nacelle are assumed as a concentrated mass at the top of the tower in the amount of $1175 \mathrm{kN}$, the rotor mass is 44 tons, and the nacelle mass 72.5 tons).

The input value of wind speed of $60 \mathrm{~m} / \mathrm{s}$ was used in the calculation, which was then corrected by three values related to the dynamic properties, shape, and size of the tower surface.

The value obtained by calculating the wind load at the level of the connection between the foundation and the wind turbine is $66583 \mathrm{kNm}$ (this value is slightly smaller than the overturning moment, which is about 70 thousand $\mathrm{kNm}$ ).

Therefore, the calculation was performed with the speed of $60 \mathrm{~m} / \mathrm{s}$ as an accidental load, and with $40 \mathrm{~m} / \mathrm{s}$ in a constant combination and the corresponding coefficients. A speed of $40 \mathrm{~m} / \mathrm{s}$ was selected as the reference maximum ten-minute mean wind speed.

\section{LOADS AND COMBINATIONS}

It is usual to verify the safety of a structure for the ultimate limit state, serviceability limit state and accidental limit state.

The structure is loaded with the following load cases:

1. Permanent

2. Ice

3. Wind $40 \mathrm{~m} / \mathrm{s}$ 
Jelčić, M., Kožul, M.

An example of wind turbine structure

\section{Wind $60 \mathrm{~m} / \mathrm{s}$}

5. Earthquake in the $\mathrm{x}$-direction

6. Earthquake in the $y$-direction

The earthquake is calculated in both directions only to prove the correctness of the calculation, because the same value is expected in both directions for a symmetrical structure and a system with one degree of freedom.

The following load combinations are taken:

1. $1.35^{\star}$ Permanent $+1.5^{*}$ ice

2. $1.35^{\star}$ Permanent $+1.5^{*}$ wind $40 \mathrm{~m} / \mathrm{s}$

3. $1.0 *$ Permanent $+1.0^{*}$ wind $60 \mathrm{~m} / \mathrm{s}$

4. $1.0 *$ Permanent $+1.0 *$ ice $+1.0 *$ earthquake $(x)$

5. $1.0 *$ Permanent $+1.0 *$ ice $+1.0^{*}$ earthquake $(y)$

The ice load was taken in the amount of $15 \%$ of the dead weight of the structure, at the top as $15 \%$ of the concentrated load from the nacelle and blades $(0.15 \times 1175 \mathrm{kN}=176 \mathrm{kN})$, and along the tower as a line load in the amount of $3 \mathrm{kN} / \mathrm{m}(15 \%$ of approx. $20 \mathrm{kN} / \mathrm{m}$ tower mass).

Furthermore, the building was also calculated for the effect of seismic ground motion, according to HRN EN 1998-1:2011, assuming the design ground acceleration $\mathrm{a}_{\mathrm{g}} / \mathrm{g}$ of 0.30 (according to the map with HRN EN 1998-1:2011/NA:2011), minimum value of the behavior factor q of 1.5 and soil category B with associated values. Spectrum type 1 was used because earthquakes with a surface wave magnitude of more than 5.5 on the Richter scale are expected. The importance factor $\gamma=1.0$ was adopted.

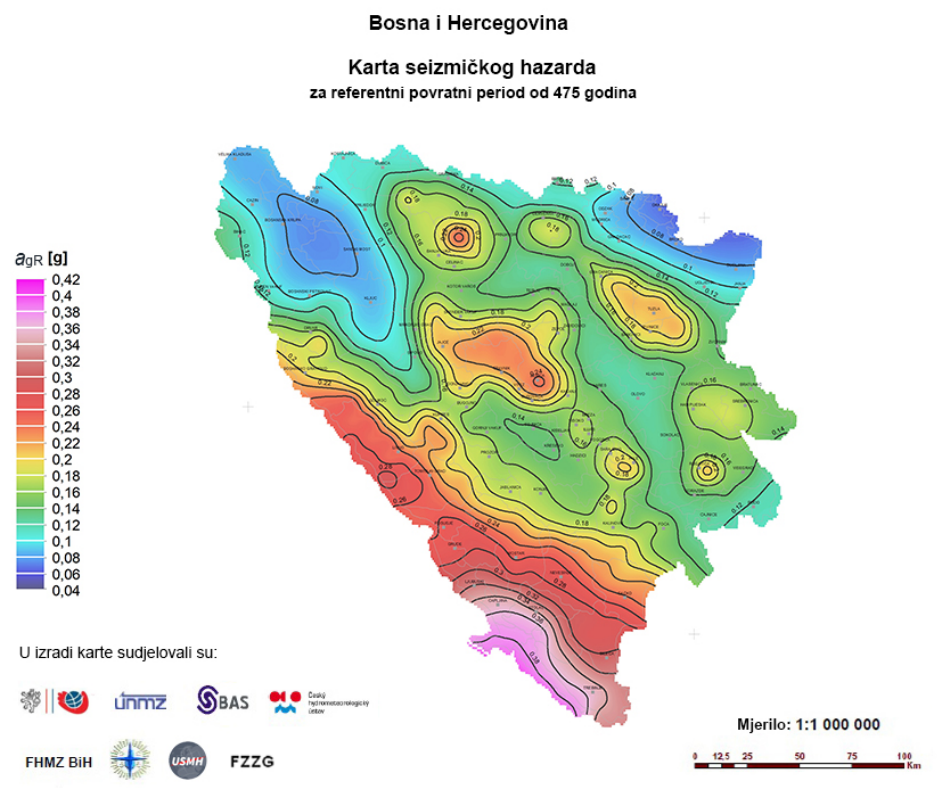

Figure 5. Seismic hazard map

The foundation is a reinforced concrete circular one, $18 \mathrm{~m}$ in diameter, $2.0 \mathrm{~m}$ in height, with a circular elevation of $50 \mathrm{~cm}$ in the middle with a diameter of $560 \mathrm{~cm}$. The relevant load for dimensioning the foundation is the wind turbine load by the current wind speed.

The foundation soil is limestone rock, the minimum bearing capacity of which exceeds $1000 \mathrm{kN} / \mathrm{m}^{2}$. The foundation is designed with concrete class C30/37 (except the top part $\mathrm{C} 35 / 45$ ) and is cross reinforced in both zones with deformed bars B500B, with $10 \mathrm{~cm}$ thick class $\mathrm{C} 20 / 25$ concrete bedding. The protective concrete layer is $5 \mathrm{~cm}$. 
Jelčić, M., Kožul, M.

An example of wind turbine structure

\section{ANALYSIS OF LOADS}

\subsection{Data on basic actions}

The basic actions for which the mechanical resistance and stability of the structure are proven are divided according to the following:

- permanent action (G) - dead weight of the structure

- variable action (Q)

- additional permanent action

- accidental action (E)

\subsubsection{Vertical loads}

\section{Dead weight of the structure}

The dead weight of load-bearing elements of the structure is determined on the basis of dimensions of the elements and specific weights of the materials from which the elements are made. The specific weight of steel is $78.50 \mathrm{kN} / \mathrm{m}^{3}$ and is generated by computer calculation. In the TOWER 7 software package, dead weight is automatically included.

\section{Weight of equipment and antennas}

The replacement weight for the equipment (nacelle) and rotors at the top of the tower is taken in the amount of $1191 \mathrm{kN}$ (rotor $471 \mathrm{kN}$ and nacelle $720 \mathrm{kN}$ ).

\section{Weight of ice}

According to DIN 4131, icing of the structure $3 \mathrm{~cm}$ in thickness was assumed, and the specific weight of ice was taken as $Y_{\mathrm{L}}=8.0 \mathrm{kN} / \mathrm{m}^{3}$.

From the ratio of the thickness of the ice and of the corresponding steel profile wall and the ratio of their specific weights, it can be assumed that the corresponding weight of ice is approximately equal to $1 / 2$ the weight of the steel structure, i.e.:

$$
\mathrm{g}_{\text {ice }} \approx \alpha \times \mathrm{g}_{\text {steel }} \approx 0.5 \mathrm{~g}_{\text {steel }} \quad \text { where } \quad \alpha \approx \frac{\alpha_{\phi}+\alpha_{L}}{2} \approx \frac{0.4+0.6}{2} \approx 0.5
$$

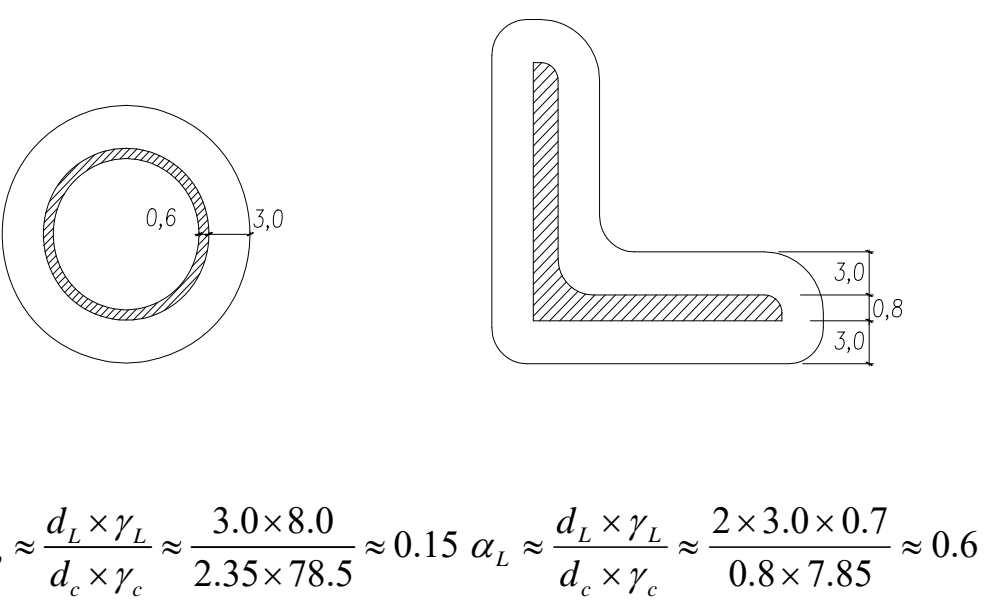

$$
\alpha_{\varphi} \approx \frac{d_{L} \times \gamma_{L}}{d_{c} \times \gamma_{c}} \approx \frac{3.0 \times 8.0}{2.35 \times 78.5} \approx 0.15 \alpha_{L} \approx \frac{d_{L} \times \gamma_{L}}{d_{c} \times \gamma_{c}} \approx \frac{2 \times 3.0 \times 0.7}{0.8 \times 7.85} \approx 0.6
$$


Jelčić, M., Kožul, M.

An example of wind turbine structure

\subsubsection{Horizontal loads}

\section{Wind load}

The action of wind is compared according to Croatian and German regulations, and further analysis of wind action is performed according to DIN 4131:

$$
w=f_{B} \times c_{f} \times w_{0} \times A
$$

According to DIN 4131, the dynamic factor $f_{B}$ was taken for the action of wind on the structure with $f_{B}=1.5$ for $T=3.28 \mathrm{~s}$, which was obtained by modal analysis of the tower structure with the software package TOWER 7.

$$
\begin{gathered}
\eta=1.05-\mathrm{h} / 1000=1.05-75.9 / 1000=0.9741 \rightarrow \eta=0.98 \text { taken } \\
\mathrm{f}_{\mathrm{B}}^{0}=1+\left(0.042 \mathrm{~T}-0.0019 \mathrm{~T}^{2}\right) \times \delta^{-0.63}=1.499 \text { where } \delta=0.1 \\
\mathrm{f}_{\mathrm{B}}=\mathrm{h} \times \mathrm{f}_{\mathrm{B}}{ }^{0}=0.98 \times 1.499=1.469 \rightarrow \mathrm{f}_{\mathrm{B}}=1.5 \text { taken }
\end{gathered}
$$

\section{Basic wind load}

The basic wind load caused by the wind speed of $\mathrm{v}_{\max }=60 \mathrm{~m} / \mathrm{s}$ was assumed, which is slightly higher than the maximum expected current wind speed according to the data. The speed is related to a return period of 50 years (Class IIA wind power plants), for an average of 3 seconds, and is $59.5 \mathrm{~m} / \mathrm{s}$. Otherwise, the facility is located in the immediate vicinity of the wind zone with $v_{b, 0}$ of $30 \mathrm{~m} / \mathrm{s}$ (on the very border with the Republic of Croatia) according to HRN EN 1991-1-4:2011+NAD NA: 2011, which is $0.56 \mathrm{kN} / \mathrm{m}^{2}$, and which, when multiplied by the coefficient of exposure $c_{e}=4$ (terrain category I, height $80 \mathrm{~m}$ ) gives $2.24 \mathrm{kN} / \mathrm{m}^{2}$, almost identical to the pressure value for the assumed speed of $60 \mathrm{~m} / \mathrm{s}$.

$$
\mathrm{w}_{\mathrm{o}}=\frac{v_{\max }^{2}}{1600}=2.25\left[\mathrm{kN} / \mathrm{m}^{2}\right]
$$

The value of $\mathrm{w}_{0}=2.3 \mathrm{kN} / \mathrm{m}^{2}$ was assumed for the calculation. The action of wind on the ice-free structure and on the icy structure with wind load reduced by the coefficient of 0.75 is observed. The wind load on the structure is determined by the expression:

$$
\mathrm{W}=\mathrm{f}_{\mathrm{d}} \times \mathrm{c}_{\mathrm{f}} \times \mathrm{w}_{0} \times \mathrm{A} \text { where } \mathrm{c}_{\mathrm{f}}=\psi \times \mathrm{c}_{\mathrm{f} 0}
$$

$\mathrm{f}_{\mathrm{d}}$ - dynamic factor (1.5)

$\mathrm{w}_{0}$ - basic respective wind load $\left(2.3 \mathrm{kN} / \mathrm{m}^{2}\right)$

A - corresponding wind exposed surface

$\mathrm{C}_{\mathrm{f} 0}-$ basic shape coefficient (1.2)

$\mathrm{C}_{\mathrm{f}}$ - corrected shape coefficient

$\psi-$ reduction factor dependent on slenderness and fullness $(0.75)$

\section{Wind load by tower height}

Determining factor $\lambda$ for heights above $50 \mathrm{~m}$ :

$$
\lambda=0.7 \times \frac{\mathrm{h}}{\mathrm{b}}=0.7 \times \frac{75.9}{3.52}=15.1
$$




\section{Segment III, upper part of the tower}

$\left.75.9 \mathrm{~m}>\mathrm{h}_{3}>46.5 \mathrm{~m} ; \mathrm{l}_{3}=29.4 \mathrm{~m} ; \mathrm{b}_{3}=2.76 \mathrm{~m}\right) \quad\left(\mathrm{b}_{3}{ }_{3}=2.82 \mathrm{~m}\right)$

The corresponding basic wind load, $\mathrm{w}_{0}=2.3 \mathrm{kN} / \mathrm{m}^{2}$

$\begin{array}{lll} & \begin{array}{l}\text { Exposed surfaces }- \text { ice-free } \\ 29.4 \times 2.76=81.1 \mathrm{~m}^{2}\end{array} & \begin{array}{l}\text { Exposed surfaces }- \text { icy } \\ 29.4 \times 2.82=82.9 \mathrm{~m}^{2}\end{array} \\ \begin{array}{l}\text { Nacelle } \\ \text { blades }\end{array} & (48.5+24.2) \times 1,00=72.7 \mathrm{~m}^{2} & (48.5+24.2) \times 1.06=77.1 \mathrm{~m}^{2} \\ & 14.0 \times 3.50=49.0 \mathrm{~m}^{2} & 14.0 \times 3.56=49.8 \mathrm{~m}^{2} \\ & \mathrm{~A}_{\circ}=202.8 \mathrm{~m}^{2} & \mathrm{~A}_{\circ}{ }^{*}=209.8 \mathrm{~m}^{2}\end{array}$

Blades + nacelle $A_{0}=121.7 \mathrm{~m}^{2}$

Blades + nacelle $A_{0}=126.9 \mathrm{~m}^{2}$

CONCENTRATED FORCE AT THE TOP OF THE TOWER:

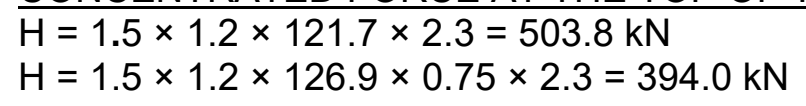

Tower, $\varphi=1$

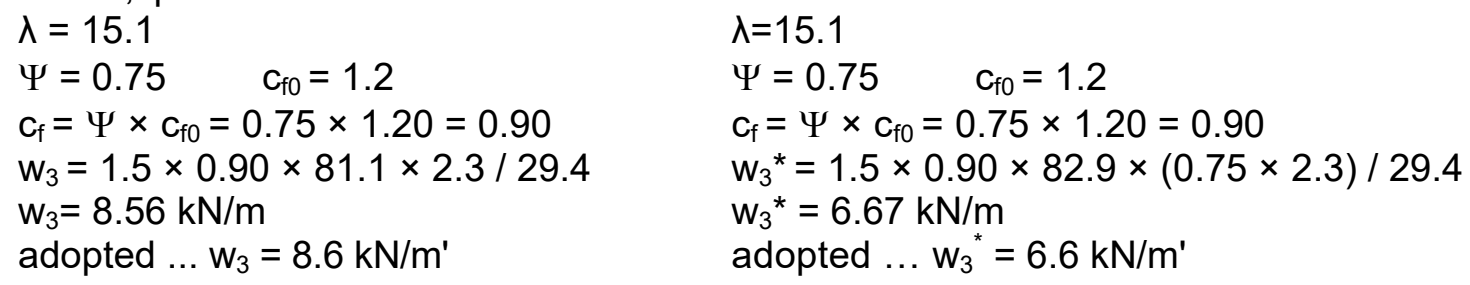

\section{Segment II, middle part of the tower}

$$
\left.46.5 \mathrm{~m}>\mathrm{h}_{2}>19.0 \mathrm{~m} ; \mathrm{l}_{2}=27.5 \mathrm{~m} ; \mathrm{b}_{2}=3.73 \mathrm{~m}\right) \quad\left(\mathrm{b}_{2}^{*}=3.79 \mathrm{~m}\right)
$$

The corresponding basic wind load, $\mathrm{w}_{0}=2.3 \mathrm{kN} / \mathrm{m}^{2}$

$\begin{array}{lll} & \text { Exposed surfaces }- \text { ice-free } & \text { Exposed surfaces }- \text { icy } \\ \text { Tower } & 27.5 \times 3.73=102.6 \mathrm{~m}^{2} & 27.5 \times 3.79=104.2 \mathrm{~m}^{2} \\ & \mathrm{~A}_{\circ}=95.5 \mathrm{~m}^{2} & \mathrm{~A}_{\circ}{ }^{*}=97.2 \mathrm{~m}^{2}\end{array}$
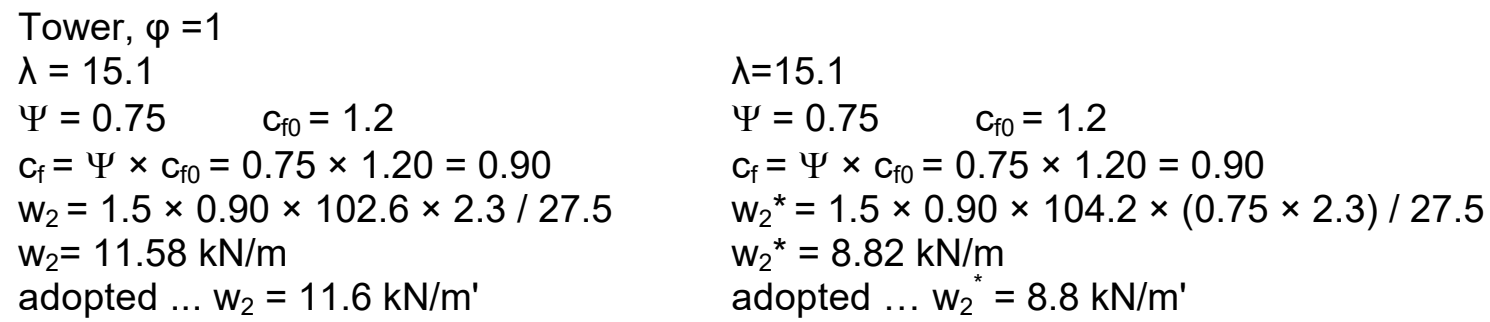


\section{Segment I, lower part of the tower}

$\left.0 \mathrm{~m}<\mathrm{h}_{1}<19.0 \mathrm{~m} ; \mathrm{l}_{1}=19.0 \mathrm{~m} ; \mathrm{b}_{1}=4.28 \mathrm{~m}\right) \quad\left(\mathrm{b}_{1}{ }_{1}=4.36 \mathrm{~m}\right)$

The corresponding basic wind load, $\mathrm{w}_{0}=2.3 \mathrm{kN} / \mathrm{m}^{2}$

$\begin{array}{lll} & \text { Exposed surfaces - ice-free } & \text { Exposed surfaces }- \text { icy } \\ \text { Tower } & 19.0 \times 4.28=81.3 \mathrm{~m}^{2} & 19.0 \times 4.36=104.2 \mathrm{~m}^{2} \\ & \mathrm{~A}_{\circ}=81.3 \mathrm{~m}^{2} & \mathrm{~A}_{\circ}{ }^{*}=82.8 \mathrm{~m}^{2}\end{array}$
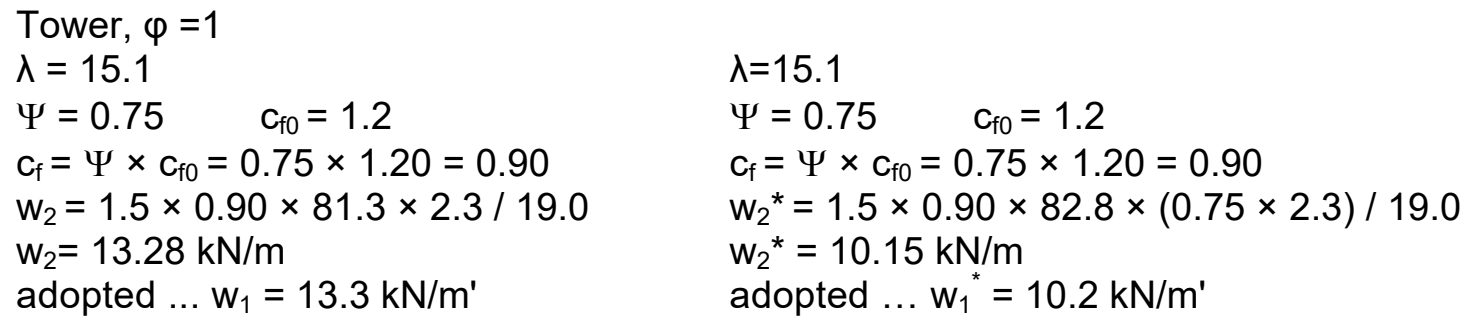

\subsection{Combinations of loads}

\subsubsection{Basic loads}

Load 1. Permanent load $=$ dead weight + rotor + nacelle

Load 2. Ice load

Load 3. Load by the wind of $40 \mathrm{~m} / \mathrm{s}$

Load 4. Load by the wind of $60 \mathrm{~m} / \mathrm{s}$

Load 5. Seismic action - direction $x$

Load 6. Seismic action - direction y

\section{Combinations of loads}

Combination 1. Permanent load + ice $(1.35 ; 1.5)$

Combination 2. Permanent load + wind $40[\mathrm{~m} / \mathrm{s}](1.35 ; 1.5)$

Combination 3. Permanent load + wind $60[\mathrm{~m} / \mathrm{s}](1.0 ; 1.0)$

Combination 4. Permanent load + seismic action $(x)+$ ice $(1.0 ; 1.0 ; 1.0)$

Combination 5. Permanent load + seismic action $(y)+$ ice $(1.0 ; 1.0 ; 1.0)$

Ice load is taken in the amount of $15 \%$ of permanent load.

For the wind speed of $40 \mathrm{~m} / \mathrm{s}$ the basic action is:

$$
\mathrm{w}_{\mathrm{o}}=\frac{v_{\max }{ }^{2}}{1600}=1,0\left[\mathrm{kN} / \mathrm{m}^{2}\right] \text { so the actions for the tower segments are: }
$$

$\mathrm{w}_{3}=1.0 / 2.3 \times 8.6=3.8 \mathrm{kN} / \mathrm{m}^{2}$

$w_{2}=1.0 / 2.3 \times 11.6=5.0 \mathrm{kN} / \mathrm{m}^{2}$

$\mathrm{w}_{1}=1.0 / 2.3 \times 13.3=5.8 \mathrm{kN} / \mathrm{m}^{2}$ 
Jelčić, M., Kožul, M.

An example of wind turbine structure

\section{STRUCTURAL CALCULATION}

Some of the wind turbine foundation and tower calculation results are shown.

Table of materals

\begin{tabular}{|c|c|c|c|c|c|c|c|}
\hline No & Material name & $\mathbf{E}\left[\mathbf{k N} / \mathbf{m}^{2}\right]$ & $\boldsymbol{\mu}$ & $\mathbf{\gamma}\left[\mathbf{k N} / \mathbf{m}^{3}\right]$ & $\mathbf{\alpha t}[\mathbf{1 / C}]$ & $\mathbf{E}\left[\mathbf{k N} / \mathbf{m}^{2}\right]$ & $\boldsymbol{\mu m}$ \\
\hline 1 & Beton MB 40 & $3.400 \mathrm{e}+7$ & 0.20 & 25.00 & $1.000 \mathrm{e}-5$ & $3.400 \mathrm{e}+7$ & 0.20 \\
\hline 2 & Beton MB 45 & $3.500 \mathrm{e}+7$ & 0.20 & 25.00 & $1.000 \mathrm{e}-5$ & $3.500 \mathrm{e}+7$ & 0.20 \\
\hline 3 & Čelik & $2.100 \mathrm{e}+8$ & 0.30 & 78.50 & $1.000 \mathrm{e}-5$ & $2.100 \mathrm{e}+8$ & 0.30 \\
\hline
\end{tabular}

\section{Plate sets}

\begin{tabular}{|c|c|c|c|c|c|c|c|c|}
\hline No & $\mathrm{d}[\mathrm{m}]$ & $\mathrm{e}[\mathrm{m}]$ & Material & Calculation type & Orthotropy & $\mathrm{E} 2\left[\mathrm{kN} / \mathrm{m}^{2}\right]$ & $G\left[k N / m^{2}\right]$ & $\alpha$ \\
\hline$\langle 1\rangle$ & 0.620 & 0.310 & 1 & Thick plate & Isotropic & & & \\
\hline$\langle 2>$ & 0.860 & 0.550 & 1 & Thick plate & Isotropic & & & \\
\hline$\langle 3\rangle$ & 1.100 & 0.790 & 1 & Thick plate & Isotropic & & & \\
\hline$\langle 4\rangle$ & 1.350 & 1.040 & 1 & Thick plate & Isotropic & & & \\
\hline$\langle 5\rangle$ & 1.590 & 1.280 & 1 & Thick plate & Isotropic & & & \\
\hline$\langle 6\rangle$ & 1.830 & 1.520 & 1 & Thick plate & Isotropic & & & \\
\hline$\langle 7\rangle$ & 1.980 & 1.670 & 1 & Thick plate & Isotropic & & & \\
\hline$<8$ & 2.500 & 2.190 & 2 & Thick plate & Isotropic & & & \\
\hline
\end{tabular}

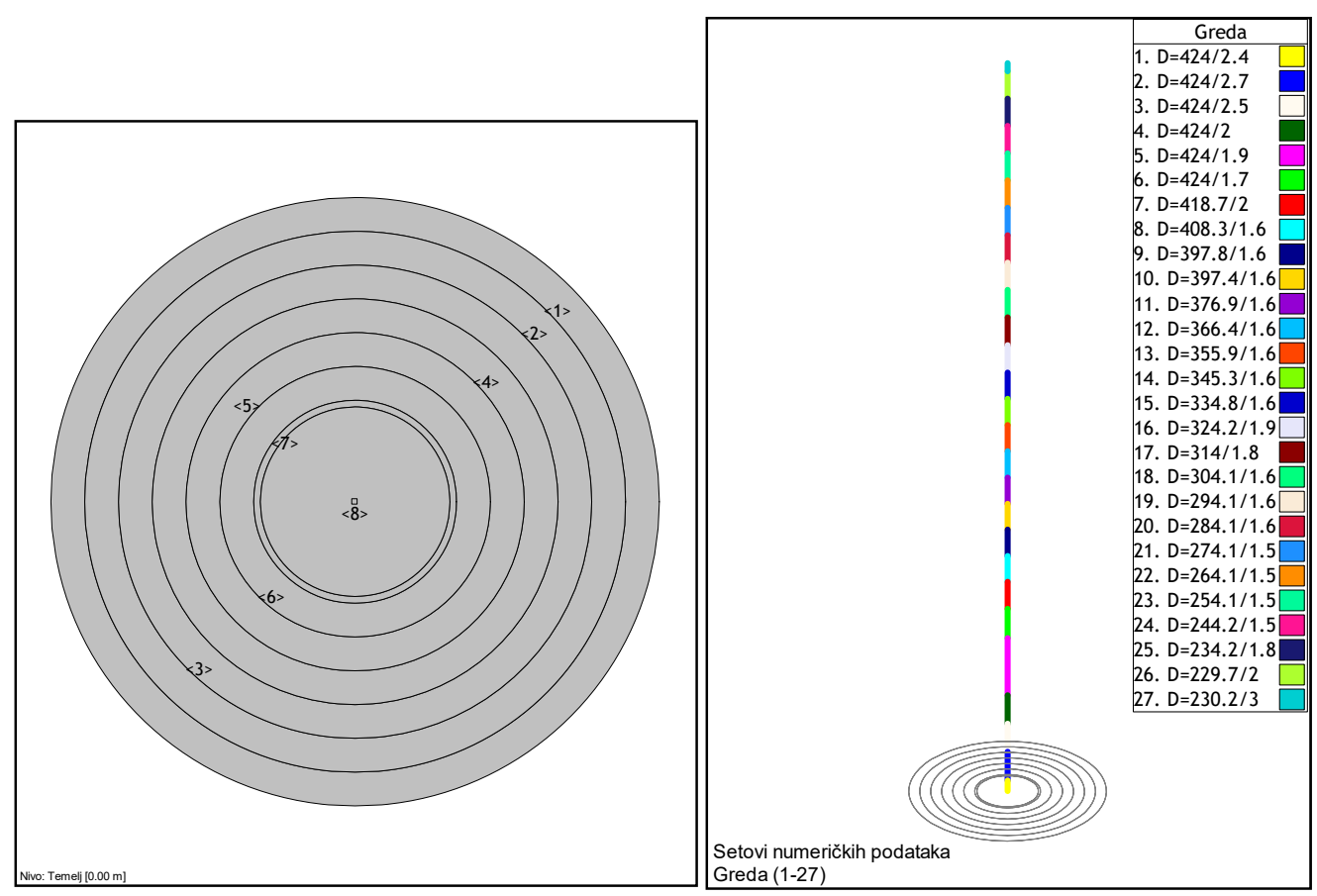


Jelčić, M., Kožul, M.

An example of wind turbine structure

List of load cases
\begin{tabular}{|c|c|}
\hline LC & Name \\
\hline 1 & Permanent $(\mathrm{g})$ \\
\hline 2 & Ice \\
\hline 3 & Wind $40 \mathrm{~m} / \mathrm{s}$ \\
\hline 4 & Wind $60 \mathrm{~m} / \mathrm{s}$ \\
\hline 5 & Sx \\
\hline 6 & Sy \\
\hline 7 & SRSS: $\mathrm{V}+\mathrm{VI}$ \\
\hline 8 & Comb.: $1.35 \mathrm{x} \mid+1.5 \mathrm{xII}$ \\
\hline 9 & Comb.: $1.35 \mathrm{x}|+1.5 \mathrm{x}| \mathrm{I}$ \\
\hline 10 & Comb.: I+IV \\
\hline 11 & Comb.: I+II+VI \\
\hline 12 & Comb.: I+|I+V \\
\hline
\end{tabular}

\section{Point loads}

\begin{tabular}{|c|c|c|c|c|c|c|c|c|c|c|}
\hline No & $\mathbf{L C}$ & $\mathbf{X}[\mathbf{m}]$ & $\mathbf{Y}[\mathbf{m}]$ & $\mathbf{Z}[\mathbf{m}]$ & $\begin{array}{c}\mathbf{P x} \\
{[\mathbf{k N}]}\end{array}$ & $\begin{array}{c}\mathbf{P y} \\
{[\mathbf{k N}]}\end{array}$ & $\begin{array}{c}\mathbf{P z} \\
{[\mathbf{k N}]}\end{array}$ & $\begin{array}{c}\mathbf{M x} \\
{[\mathbf{k N m}]}\end{array}$ & $\begin{array}{c}\text { My } \\
{[\mathbf{k N m}]}\end{array}$ & $\begin{array}{c}\text { Mz } \\
{[\mathbf{k N m}]}\end{array}$ \\
\hline 1 & 1 & 9.0000 & 9.0000 & 75.910 & & & -1175.0 & & & \\
\hline 2 & 2 & 9.0000 & 9.0000 & 75.910 & & & -177.00 & & & \\
\hline 3 & 3 & 9.0000 & 9.0000 & 75.910 & 219.00 & & & & & \\
\hline 4 & 4 & 9.0000 & 9.0000 & 75.910 & 503.80 & & & & & \\
\hline
\end{tabular}

\section{Load factors for calculation of masses}

\begin{tabular}{|c|c|c|}
\hline No & Name & Coefficient \\
\hline 1 & Permanent $(\mathrm{g})$ & 1.00 \\
\hline 2 & Ice & 1.00 \\
\hline 3 & Wind $40 \mathrm{~m} / \mathrm{s}$ & 0.00 \\
\hline 4 & Wind $60 \mathrm{~m} / \mathrm{s}$ & 0.00 \\
\hline
\end{tabular}

\section{Structure oscillation periods}

\begin{tabular}{|c|c|c|}
\hline No & $\mathbf{T}[\mathbf{s}]$ & $\mathbf{f}[\mathbf{H z}]$ \\
\hline 1 & 3.3231 & 0.3009 \\
\hline 2 & 3.3231 & 0.3009 \\
\hline 3 & 0.3980 & 2.5128 \\
\hline 4 & 0.3980 & 2.5128 \\
\hline 5 & 0.1381 & 7.2402 \\
\hline 6 & 0.1381 & 7.2402 \\
\hline 7 & 0.0700 & 14.2946 \\
\hline 8 & 0.0700 & 14.2946 \\
\hline 9 & 0.0430 & 23.2645 \\
\hline 10 & 0.0430 & 23.2645 \\
\hline 11 & 0.0297 & 33.6649 \\
\hline 12 & 0.0297 & 33.6649 \\
\hline 13 & 0.0268 & 37.2446 \\
\hline 14 & 0.0268 & 37.2446 \\
\hline 15 & 0.0263 & 37.9925 \\
\hline
\end{tabular}


Jelčić, M., Kožul, M.

An example of wind turbine structure

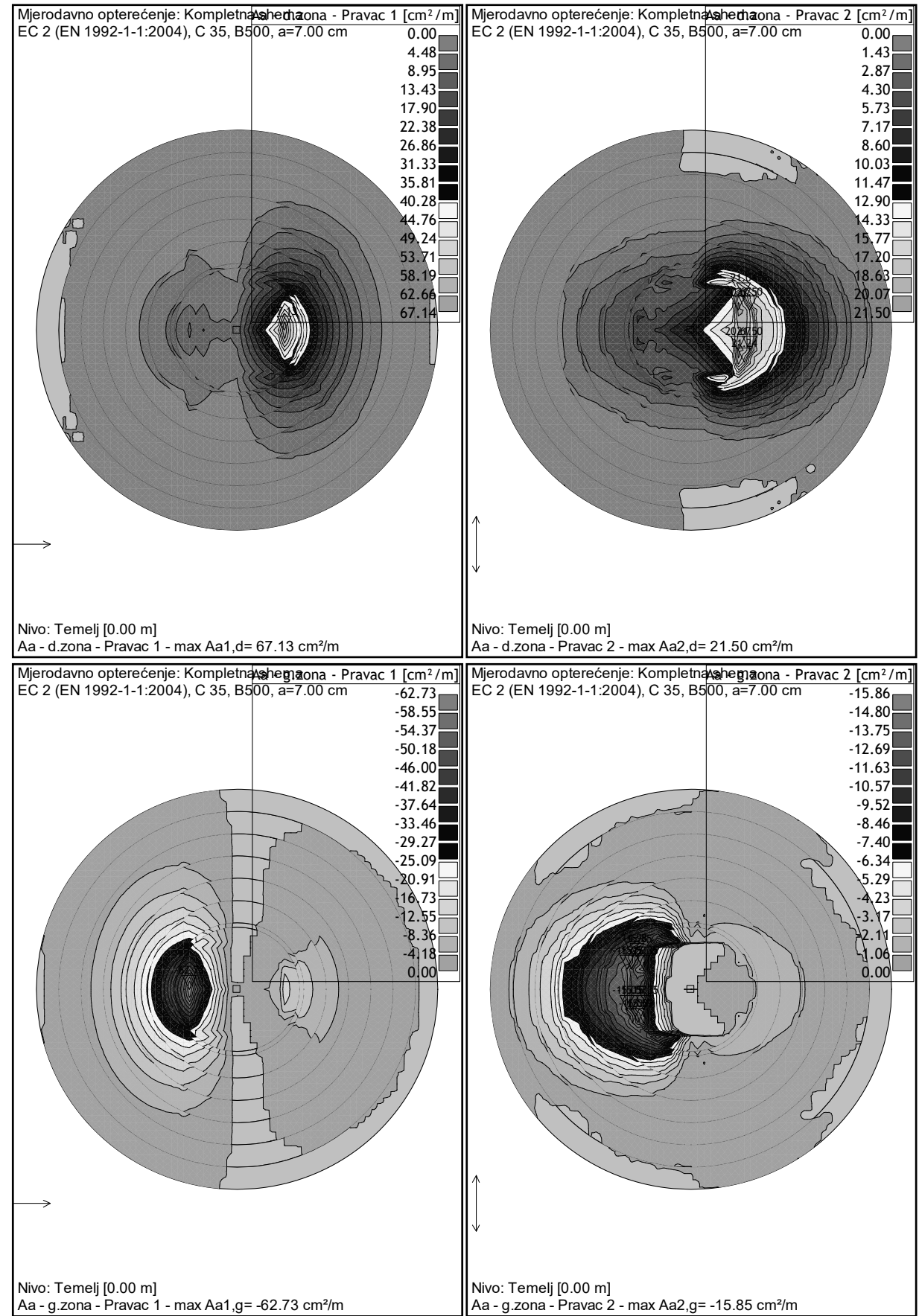




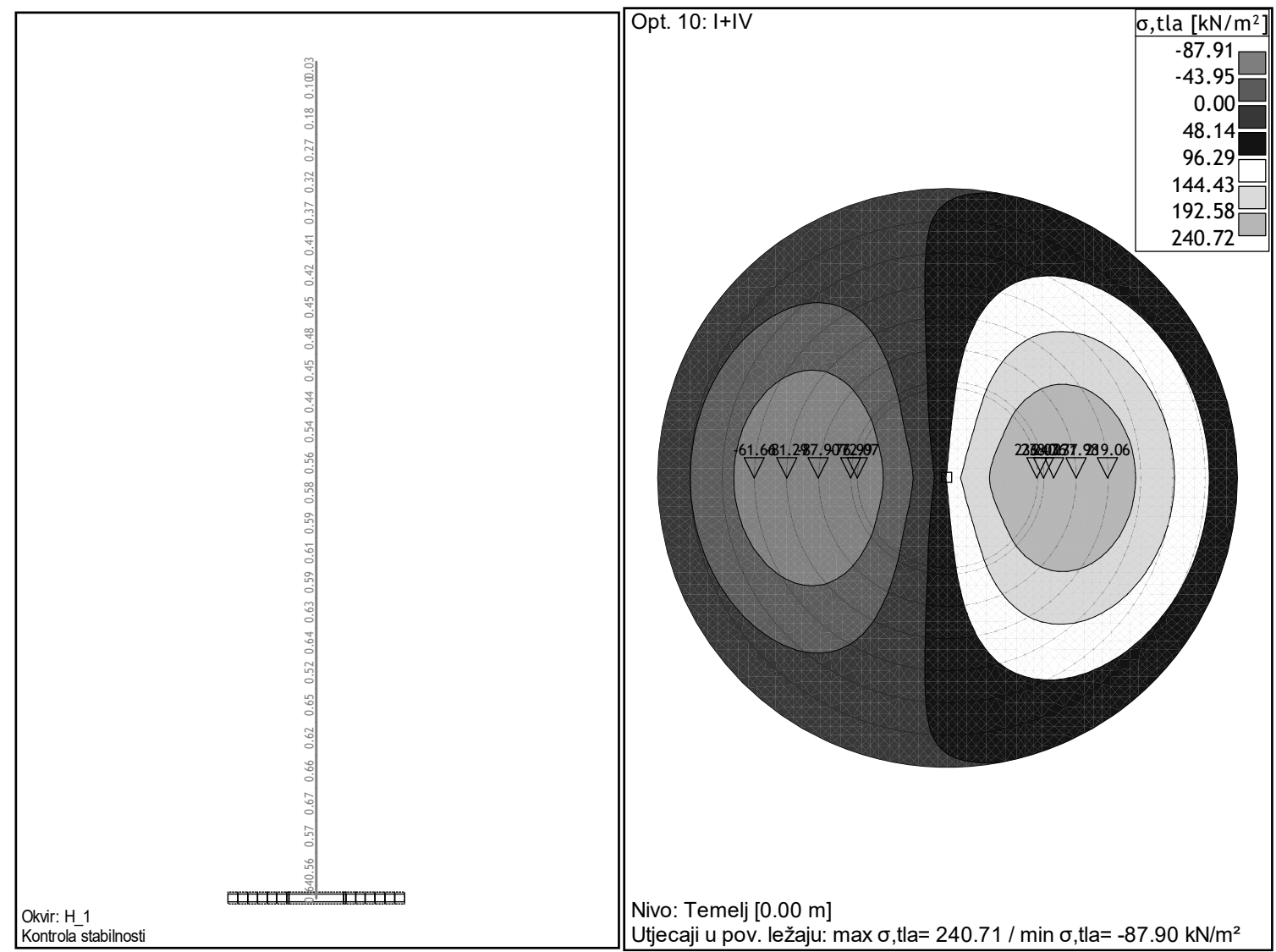

\section{CONCLUSION}

Preliminary structural calculation of the wind turbine structure (foundation and tower) was performed here. Soil characteristics, wind load data, as well as the seismic zone in which the structure is located were available. Selecting the type of structure is a complex task for wind power plants. The decision is influenced by economic and environmental factors, the type of structure, and the shape and size of the wind turbine. An inverted pendulum system was selected for this structure. Therefore, the purpose of this work was to perform the calculation of this structural system and check whether it meets the load-bearing capacity and stability requirements.

The calculation was performed according to the load bearing capacity on the spatial model, in the computer program Tower 7 . That model will rarely be a true picture of actual behavior of the structure. These are always only more or less rough approximations or simplified realities.

The structural calculation was performed on all load-bearing structural elements and on the basis of the obtained results we can conclude that the structural system meets the prescribed load-bearing capacity and structural stability criteria. In the analysis of the obtained effects, there were no deviations from the values allowed by the rules. Accordingly, it is possible to assume that the subject structure will perform well in reality. 


\section{REFERENCES}

1. Eurocode 0, Basis of structural design, CEN European Committee for Standardization, Brussels, EN 1990: 2002.

2. EN 1991: Eurokod 1 - Djelovanja na konstrukcije (EN 1991:2002).

3. Eurocode 8 - Design of structures for earthquake resistance - Part 1: General rules, seismic actions and rules for buildings, European Committee for Standardization, CEN, Brussels, EN 1998-1: 2004.

4. N. Čupin - Nova energetika - energetika u službi gospodarstva, Zagreb, 2013.

5. M. Čaušević - Dinamika konstrukcija - diskretni sustavi, Zagreb, 2005.

6. Građevinar 57 (2005) 6.

7. A. Štefulj - Završni rad - Vjetroelektrane, Rijeka, 2015.

8. Građevinar 70 (2018) 12.

9. Građevinar 69 (2017) 1.

10. Obnovljiva energija - https://hr.wikipedia.org/wiki/Obnovljiva_energija\#Energija_vjetra.

11. D. Županić - Diplomski rad, Zagreb, 2015.

12. International Standard - IEC 61400-1; Wind turbines - part 1: Design requirements 